\title{
PENGEMBANGAN BAHAN AJAR BERBASIS PEMBELAJARAN MATEMATIKA REALISTIK UNTUK MENINGKATKAN KEMAMPUAN KOMUNIKASI MATEMATIS SISWA
}

\author{
Nurhafizhoh Siregar ${ }^{1}$, Kms.Amin Fauzi ${ }^{2}$, Hasratuddin ${ }^{3}$ \\ ${ }^{1}$ Program Studi Magister Pendidikan Matematika, Universitas Muslim Nusantara Al-Washliyah \\ ${ }^{2,3}$ Program Studi Magister Pendidikan Matematika, Universitas Negeri Medan \\ Email: ${ }^{1}$ nurhafizohsiregar@gmail.com
}

\begin{abstract}
ABSTRAK
Penelitian ini bertujuan menganalisis peningkatan kemampuan komunikasi matematis melalui bahan ajar yang dikembangkan berbasis pembelajaran matematika realistik, menemukan bahan ajar yang efektif berbasis Pembelajaran Matematika Realistik, menemukan karakter bahan ajar berbasis Pembelajaran Matematika Realistik dalam meningkatan kemampuan komunikasi matematis dan menganalisis perbedaan kemampuan komunikasi matematis siswa antara siswa yang diberi pembelajaran matematis realistik dengan siswa pada pendekatan ekspositori siswa. Jenis penelitian ini adalah Reseacrh and Development (R\&D) dengang Model ADDIE (Analyze, Design, Developmet, Implementation and Evaluation). Subjek dalam penelitian ini adalah seluruh peserta didik SD Negeri 060791 Medan Area yang terdiri dari dua kelas yaitu kelas V masing-masing sebanyak 20 peserta didik dan objek penelitian adalah pengembangan bahan ajar berbasis Pembelajaran Matematika Realistik (PMR) yang berupa buku guru dan siswa. Hasil yang diperoleh dalam penelitian ini adalah (1) Terdapat peningkatan Kemampuan komunikasi matematis melalui bahan ajar yang dikembangkan berbasis pembelajaran matematika realistik siswa SD Negeri 060791 Medan Area; (2) Bahan ajar berbasis Pembelajaran Matematika Realistik yang dihasilkan efektif digunakan dalam meningkatan kemampuan komunikasi matematis siswa SD Negeri 060791 Medan Area; (3) Terdapat peningkatan karakteristik bahan ajar yang efektif dalam kemampuan komunikasi matematis siswa yang dihasilkan dalam penelitian adalah Self instructional, Self Contained dan User friendly dan (4) Terdapat perbedaan kemampuan komunikasi matematis siswa antara siswa yang diberi pembelajaran matematis realistik dengan siswa pada pendekatan ekspositori siswa SD Negeri 060791 Medan Area.
\end{abstract}

Kata Kunci: Bahan Ajar, PMR, Kemampuan Komunikasi Matematis

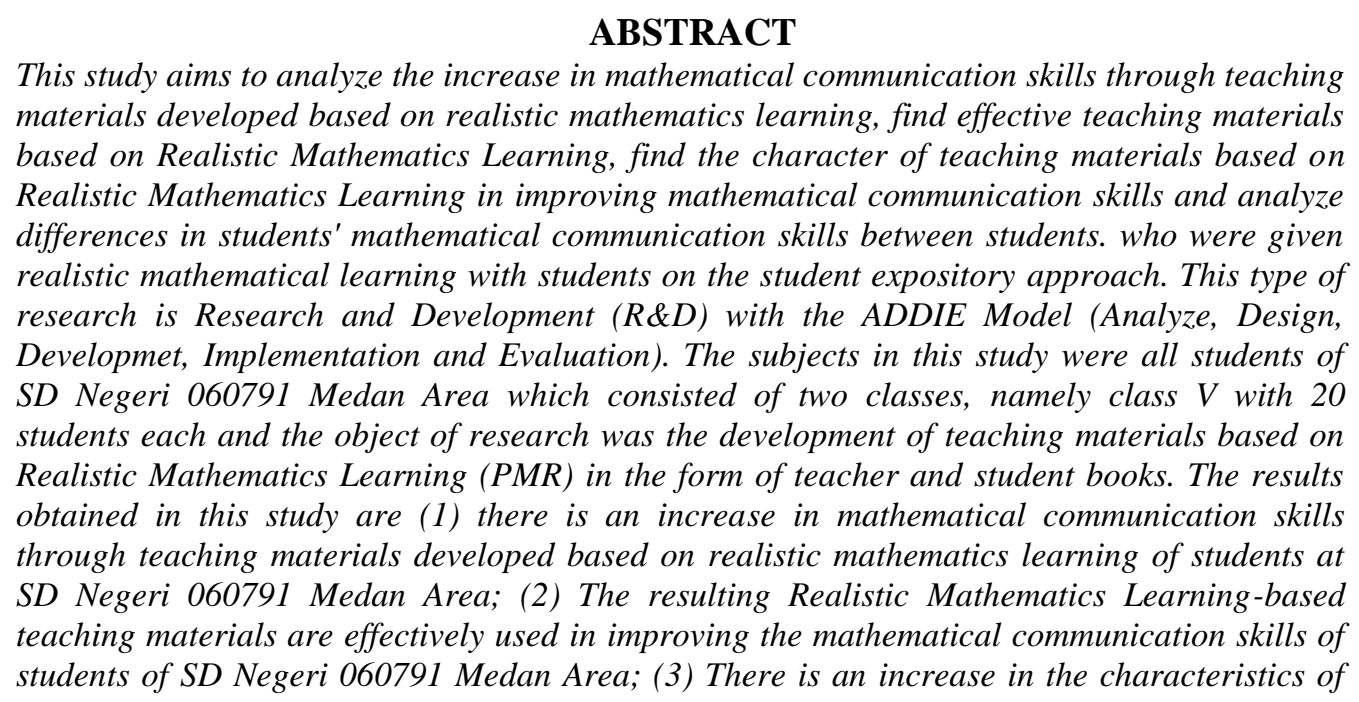


teaching materials that are effective in students 'mathematical communication skills produced in the study, namely Self-instructional, Self-Contained and User-friendly and (4) There are differences in students' mathematical communication abilities between students who are given realistic mathematical learning with students in the expository approach. students of SD Negeri 060791 Medan Area.

Keywords: Teaching Materials, PMR, Mathematical Communication Skills

\section{PENDAHULUAN}

Berdasarkan sejarah matematika, matematika lahir didasari oleh beberapa konsep diantaranya adalah konsep bilangan, besaran, dan bangun. Matematika banyak terdapat proses kehidupan sehari-hari, bahkan matematika dasar perkembangan Ilmu Pengetahuan dan Teknologi (IPTEK), sehingga setiap insan manusia harus menyadari bahwa matematika adalah ratu pengetahuan. Pentingnya matematika dalam perkembangan ilmu pengetahuan dan kehidupan sehari-hari, menuntut setiap manusia mengerti dan memaknai adanya matematika dengan baik. Indonesia merupakan negara yang mengembangkan matematika menjadi salah satu mata pelajaran yang wajib diberikan kepada setiap peserta didik, pada kurikulum 2013 dengan jelas menekankan pendidikan matematika dapat diartikan sebagai proses perubahan baik kognitif, afektif, dan kognitif kearah kedewasaan sesuai dengan kebenaran logika.

Hal ini menuntut peserta didik harus mampu cara berpikir matematika sistematis, melalui urutan-urutan yang teratur dan tertentu, cara berpikir matematika secara deduktif, belajar matematika melatih kita menjadi manusia yang lebih teliti, cermat, dan tidak ceroboh dalam bertindak. Belajar matematika mengajarkan kita menjadi orang yang sabar dalam menghadapi semua hal dalam hidup ini dan banyak penerapan matematika dalam kehidupan nyata (Purnama, I. M., 2016).

Sritresna (2016) juga menegaskan bahwa kemampuan komunikasi matematis tidak sesuai dengan yang diharapkan. Hal ini menunjukkan bahwa masih rendahnya kemampuan komunikasi matematis siswa, berdasarkan hasil studi Programme for International Student Assessment (PISA) 2018 telah dirilis pada hari Selasa, 3 Desember 2019. PISA (Program untuk Pelajar Internasional) yang diadakan pada tahun 2018 bertujuan untuk mengukur tingkat kemampuan komunikasi matematis peserta didik. Indonesia berada di peringkat 7 dari bawah (73) dengan skor rata-rata 379. Indonesia berada di atas Arab Saudi yang memiliki skor rata-rata 373. Kemudian untuk peringkat satu, masih diduduki China dengan skor ratarata 591.

Hal tersebut juga terlihat pada hasil observasi awal di SD Negeri 060791 Medan Area, Siswa SD Negeri 060791 Medan Area belum mampu mengembangkan kemampuan komunikasi matematis siswa, terlihat pada persentase jumlah peserta didik kelas VA yang memenuhi KKM hanya sebesar 35\% sedangkan yanng tidak memenuhi KKM sebesar 65 $\%$. Kemudian peserta didik kelas VB yang memenuhi KKM hanya sebesar $33 \%$ sedangkan yang tidak memenuhi KKM sebesar $67 \%$. Hal ini juga dikemukan oleh beberapa guru matematika dilokasi tersebut, alasan terbesar adalah kurang mampunyai guru dalam menciptakan suasana pembelajaran, keterbatasan waktu dan keterbatasan bahan ajar. Peserta didik masih mengalami kesulitan dalam proses soal mencari (Problem to find) dalam menentukan atau mendapatkan nilai atau objek tertentu yang tidak diketahui dalam soal dan soal membuktikan (problem to prove) dalam menyelesaikan sesuai dengan prosedur untuk menentukan apakah suatu pernyataan benar atau tidak benar. Maka permasalahan yang menjadi bahan pertimbangan perbaikan adalah bahan yang diberikan kepada peserta didik dan guru harus lebih menarik lagi sehingga siswa bisa lebih meningkatkan kemampuan komunikasi untuk mempermudah proses pembelajaran dan pencapaian tujuan pembelajaran. Untuk demikian perlu dikembangkan bahan ajar berupa buku peserta didik dan buku guru yang akan memudahkan pemahaman peserta didik dalam memahami materi, sehingga bahan 
ajar dikembangkan berdasarkan penilaian sampul buku, indikator pembelajaran hingga materi dan latihan yang ditawarkan hingga proses pembelajaran. Pengembangan buku peserta didik merupakan kompotensi profesional seorang guru, yang dikemukakan dalam undang-undang nomor 14 tahun 2005 pasal 10 ayat 1 dinyatakan bahwa seorang guru harus memiliki beberapa kompetensi, salah satunya kompetensi profesional yaitu guru dituntut untuk memiliki semangat profesionalisme yang tinggi diantaranya kemampuan dalam mengembangkan bahan ajar (Hasanah, 2012). Dengan demikian, bahan ajar sangat tepat menjadi solusi yang dapat digunakan untuk menyelesaikan permasalahan yang dihadapi peserta didik didalam kelas.

Dalam hal ini juga ditegaskan bahwa pengembangan buku peserta didik dalam meningkatkan komunikasi matematis, akan diaplikasikan dengan menggunakan pendekatan Pendidikan Matematika Realistik (PMR). PMR sangat tepat digunakan karena berkaitan dengan materi yang disajikan yaitu mengutamakan kehidupan sehari-hari. Menurut Komalasari (Afrom, 2019) mengemukakan bahwa, "Pendekatan diartikan titik tolak atau sudut pandang kita terhadap proses pembelajaran, yang merujuk pada pandangan tentang terjadinya suatu proses yang sifatnya masih sangat umum, di dalamnya mewadahi, menginspirasi, menguatkan, dan melatari metode pembelajaran dengan cakupan teoritis tertentu." Guru perlu melakukan pemilihan pendekatan pembelajaran yang sesuai dengan tingkat perkembangan peserta didik agar dapat mencapai tujuan pembelajaran yang diinginkan. Pendekatan pembelajaran yang dibahas dalam kajian teori ini adalah pendekatan Pendidikan Matematika Realistik (PMR).

Hal ini ditegaskan oleh (Islam, 2016) bahwa kemampuan komunikasi matematis peserta didik berdasarkan indikator yang muncul setelah diterapkan pendekatan PMR dapat diurutkan dari indikator yang paling mudah dipahami hingga yang paling sukar dipahami peserta didik dalam soal kuis diantaranya adalah menyatakan situasi, gambar, diagram, atau benda nyata ke dalam bahasa, simbol, ide, atau model matematika, menjelaskan suatu ide, situasi, dan relasi matematika melalui tulisan, memberikan alasan atau bukti atas kebenaran solusi, dan memeriksa kesahihan suatu argument dan kemampuan komunikasi matematis peserta didik dengan menerapkan Pendidikan Matematika Realistik lebih baik daripada kemampuan komunikasi matematis peserta didik dengan menerapkan pembelajaran konvensional di kelas VII MTsN Lubuk Buaya Padang.

Buku ajar juga merupakan salah satu hal yang penting dalam proses pembelajaran. Bahan ajar menurut (Sumiati, et al., 2017) menjelaskan bahwa segala bahan (baik informasi, alat, maupun teks) yang disusun secara sistematis, yang menampilkan sosok utuh dari kompetensi yang akan dikuasai peserta didik dan digunakan dalam proses pembelajaran dengan tujuan perencanaan dan penelaahan implementasi pembelajaran. Menurut (Kurbaita, et al., 2013) buku peserta didik merupakan buku yang dipegang oleh peserta didik memuat konten yang sama dengan buku guru. Hanya dalam buku peserta didik tidak disertakan keterangan yang ditunjukkan seperti pada gambar buku guru. Buku peserta didik merupakan buku yang menjadi pegangan peserta didik dalam mempelajari materi waktu dengan menggunakan model pembelajaran PMR di kelas.

Berdasarkan uraian diatas maka diduga pengembangan bahan ajar berbasis masalah menggunakan pembelajaran matematika realistik mampu melatih kemampuan komunikasi matematis siswa. Penelitian ini juga ditegaskan oleh (Umar, 2012) diperoleh hasil bahwa peserta didik ketika ditantang untuk mengomunikasikan alasan mereka baik secara lisan maupun tertulis, peserta didik menikmati matematika lebih banyak dan berpikir matematika itu lebih menyenangkan, artinya peserta didik mampu mengomunikasikan pemikiran dan penalaran mereka baik secara lisan maupun tertulis. Oleh karena itu, peneliti akan melakukan penelitian tentang pengembangan bahan ajar berbasis pembelajaran matematika realistik untuk meningkatan kemampuan komunikasi matematis siswa. 


\section{METODE}

Jenis Penelitian adalah penelitian dan pengembangan (Research and Development) dengan menghasilkan produk berupa bahan ajar dalam bentuk buku guru dan buku peserta didik untuk meningkatkan kemampuan komunikasi matematis melalui pendekatan Pendidikan Matematika Realistik (PMR). Produk pembelajaran bahan ajar, model pengembangan yang diacu oleh peneliti adalah model pengembangan Analysis, Design, Development, Implementation and Evaluation (ADDIE). ADDIE merupakan kerangka kerja yang runut dan sistematis dalam mengorganisasikan rangkaian kegiatan penelitian desain dan pengembangan. Secara skema, model pengembangan produk pembelajaran dengan mengembangkan bahan ajar (buku guru dan peserta didik) berbasis pembelajaran realistik dalam meningkatkan komunikasi matematika peserta didik. Mode pengembangan ADDIE dapat digambarkan sebagai berikut :

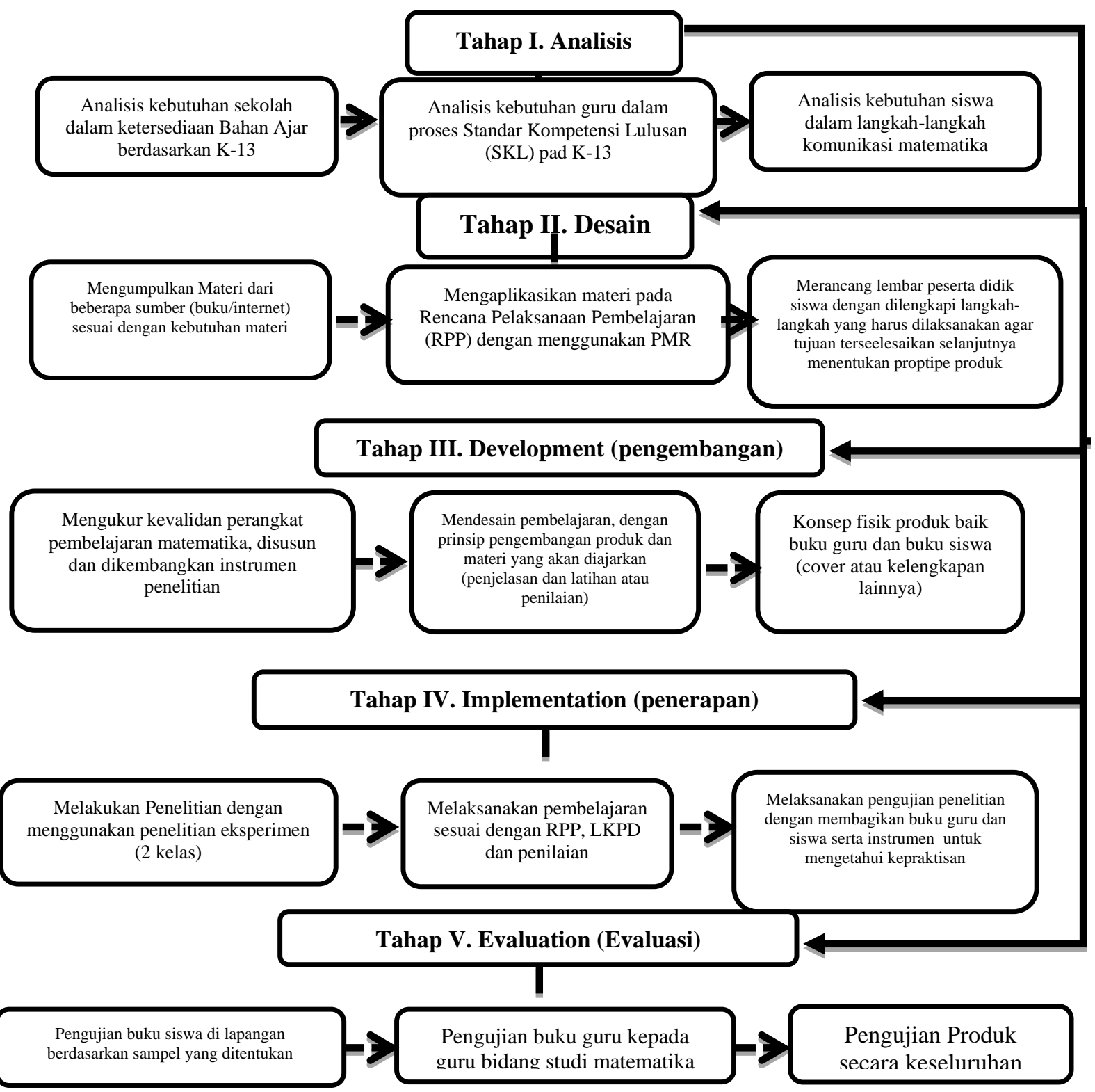

Gambar 1. Model Prosedur Pengembangan Produk dengan Kerangka ADDIE (Rusdi; 2018:121) Keterangan gambar: 


\section{HASIL}

\section{: Kegiatan Setiap Langkah-Langkah ADDIE}

Hasil uji coba bahan ajar berbentuk buku guru dan buku siswa. Pada penelitian dan pengembangan ini menghasilkan produk berupa aplikasi bahan ajar interaktif pada mata pelajaran matematika di Sekolah Dasar. Produk bahan ajar merupakan salah satu aplikasi buku guru dan buku siswa yang disesuaikan dengan kebutuhan setiap permasalahan. Tahapan validasi ahli untuk produk bahan ajar sudah dilaksanakan. Hasil yang diperoleh produk dinyatakan valid tanpa revisi, hal ini dikarenakan hasil setiap aspek kelayakan isi, kelayakan bahasa, kelayakan penyajian dan kelayakan kegrafikan berada pada nilai rata-rata lebih besar dari 2,75 .

Dalam penelitian ini peserta didik yang diberikan produk buku siswa serta mengaplikasikan proses belajar dengan PMR memiliki kemampuan komunikasi matematis sangat baik dengan nilai rata-rata keberhasilan menyelesaikan instrumen sebesar 81,19 pada kelas eksperimen 1, sedangkan kelas eksperimen 2 yang hanya menggunakan buku paket serta pembelajaran ekspositori dengan kategori baik dengan nilai sebesar 70,48.

Produk buku guru digunakan dalam proses belajar mengajar, selanjutnya peserta didik memberikan respon positif dengan hasil yang diperoleh respon siswa dalam menilai terhadap kegiatan pembelajaran sebesar 91,11\% dengan kategori sangat baik dan penilaian pada buku siswa sebesar $91,83 \%$ dengan kategori sangat baik. Dengan demikian dapat disimpulkan bahwa respon peserta didik terhadap buku siswa berbasis PMR

Berikut bentuk cover pada desain akhir dalam proses pengembangan bahan ajar

Tabel 1. Desain Cover Bahan Ajar

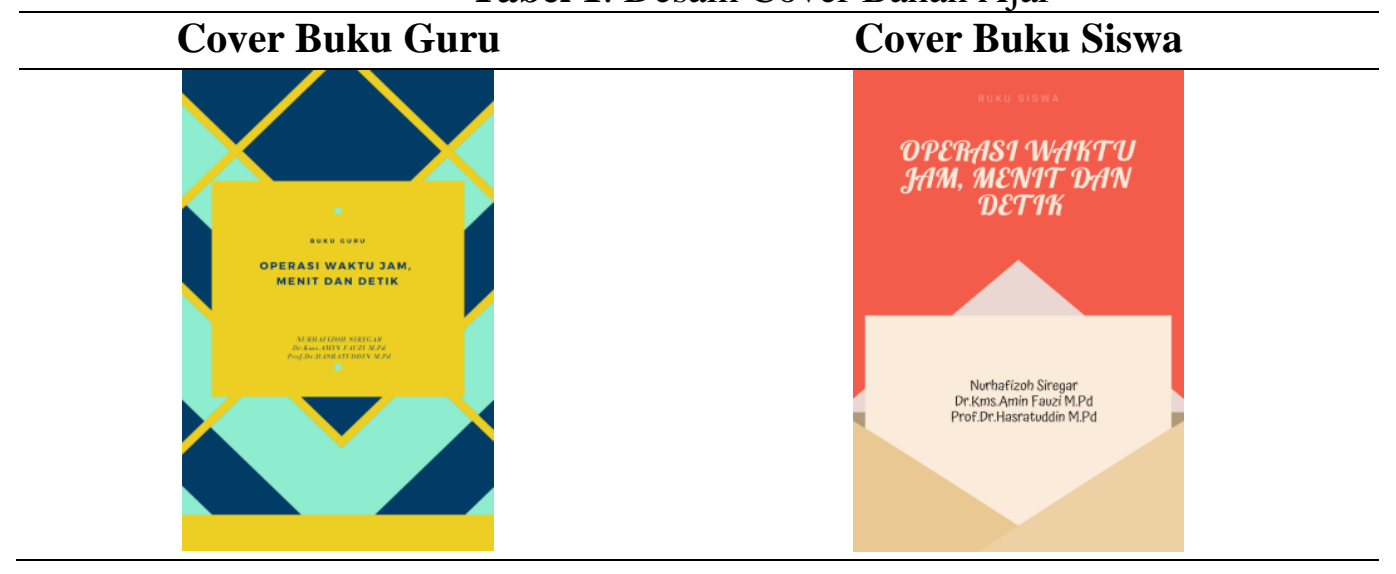

Tabel 2. Komponen Isi Bahan Ajar

\section{Cover Buku Guru}

Cover Buku Siswa 


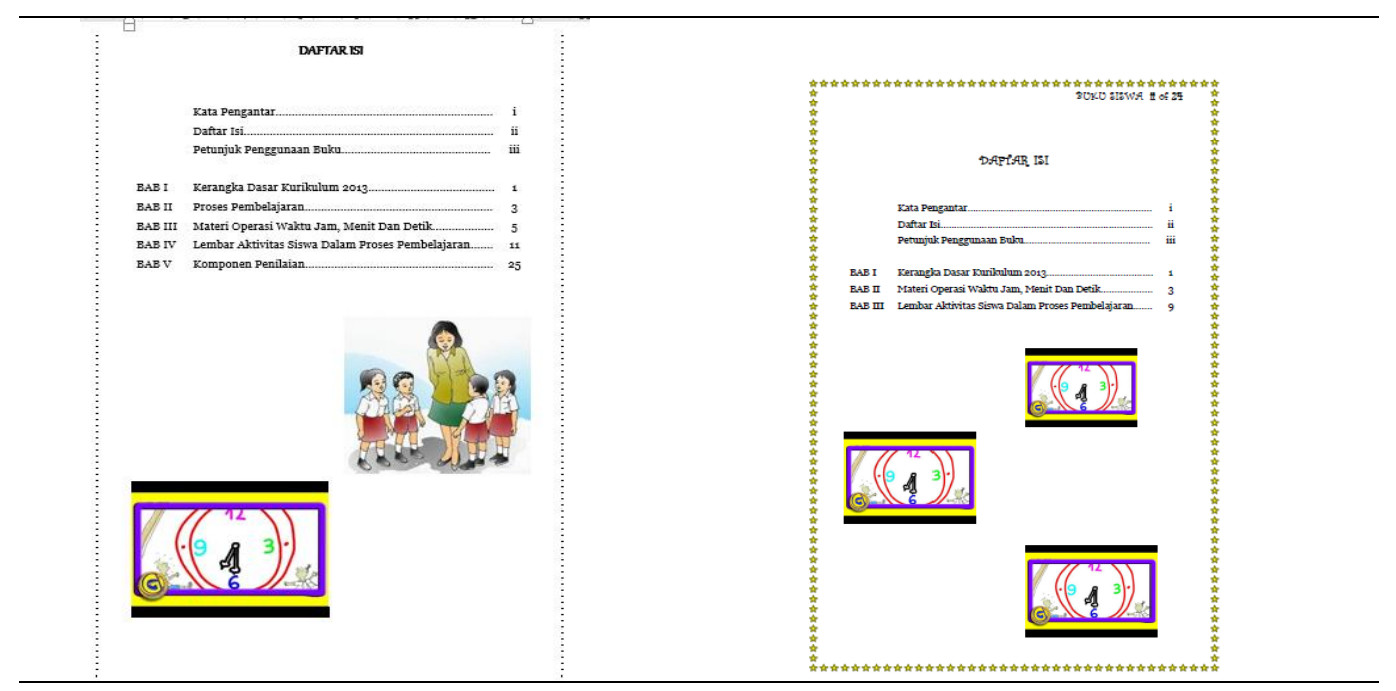

Dalam buku disediakan beberapa nama kegiatan dalam pembelajaran

a. Sikapku: menguatkan peserta didik agar dapat mewujudkan pengetahuan dalam perilaku.

b. Ayo semangat: kegiatan yang harus peserta didik kerjakan untuk memahami materi.

c. Aku detektif: tantangan agar peserta didik bisa melakukannya.

d. Ayo bersosialisasi: siswa berinteraksi dengan guru dan siswa

e. Ayo berbicara: pengukuran penguasaan peserta didik terhadap materi yang dibahas.

Hasil pencapaian skor dari buku guru lebih besar dari 2,75 yang artinya layak digunakan tanpa revisi. sehingga validasi hanya dilakukan satu kali oleh validator ahli. Sama halnya dengan buku guru hasil pencapaian skor dari buku siswa lebih besar dari 2,75 yang artinya layak digunakan tanpa revisi. Sehingga hal tersebut dilakukan hanya satu kali validasi oleh validator ahli.

\section{PEMBAHASAN}

Berdasarkan model pengembangan ADDIE, langkah-langkah pengembangan media Buku Guru dan Buku Siswa pada materi operasi hitung satuan waktu jam, menit, dan detik siswa kelas V SD Negeri 060791 Medan Area dilakukan melalui tahap berikut:

1. Tahap Analysis

a. Analisis Kebutuhan

Analisis kebutuhan kurikulum berhubungan dengan analisis tujuan belajar.

b. Analisis Karakteristik Siswa

Analisis karakteristik siswa mencakup minat, bakat, keterbatasan, dan kelebihan individual.

c. Analisis Kemampuan Prasyarat dan Kemampuan Awal

Tingkat perkembangan aktual kelihatan dari kemampuan anak menyelesaikan tugas secara mandiri, sedangkan tingkat perkembangan potensial terlihat pada kemampuan anak memecahkan masalah yang lebih tinggi dengan bantuan orang dewasa.

d. Anaslisis Lingkungan Belajar 
Analisis lingkungan belajar dapat mencakup tentang budaya belajar di sekolah, budaya belajar di kelas, pola interaksi guru dengan siswa dan siswa dengan siswa, potensi keterlibatan siswa dalam proses belajar, ketersediaan sumber belajar, ketersediaan sarana teknologi informasi dan pendukung lainnya.

2. Tahap Design

a. Menentukan Tim Pengembang

Tim pengembang terdiri dari pengembang utama, validator ahli, validator praktisi, programmer, teknisi dan pengguna.

b. Menemukan Sumber Daya yang Dibutuhkan

Sumber daya dianalisis untuk dipastikan bahwa apa yang dibutuhkan untuk pengembangan terpenuhi sebelum kegiatan pengembangan tersebut dimulai.

c. Menyusun Jadwal Pengembangan

Pengembang dengan tim perlu menyusun jadwal secara terinci, tahap demi tahap agar pencapaian kemajuan dapat terukur secara baik. Melalui jadwal yang telah disepakati, semua anggota tim pengembang berkomitmen menyelesaikan

d. Memilih dan Menentukan Cakupan, Pembelajaran

Materi ajar di organisir dalam peta pikiran (mind map), peta konsep (concept map), atau diagram alir (flow chart) yang dapat menggambarkan kata kunci yang akan disajikan dalam materi tersebut dan keterkaitannya satu sama lain.

e. Pembuatan Storyboard

Pembuatan storyboard sangat penting bagi pengembangan media pembelajaran elektronik, seperti media animasi dan simulasi dan video pembelajaran.

f. Menentukan Spesifikasi Produk

Spesifikasi produk ditentukan dari penentuan persyaratan produk saat analisis awal dilakukan.

g. Membuat Prototipe Produk

Pembuatan prototipe ini tim pengembang mensinergikan, mengintegrasikan pengalaman, pengetahuan, kompetensi, estetika, dan sumber dayanya untuk menghasilkan produk awal yang sesuai spesifikasi produk yang telah ditentukan.

3. Tahap Development

a. Validasi Ahli

Aspek konseptual yang divalidasi meliputi: aspek desain pembelajaran, aspek pedagogis atau andragogis atau heutagogis, prinsip-prinsip pengembangan produk, konsep fisik produk, materi ajar dan pesan yang akan disampaikan melalui produk tersebut.

b. Validasi Praktisi

Pandangan praktisi terhadap produk menjadi jembatan penghubung antara pandangan konseptual ahli dengan pengguna akhir dalam aspek praktikalitas produk.

4. Tahap Implementasi

Tahapan implementasi dilakukan ujicoba pada 30 siswa kelas V SD Negeri 060791 Medan Area, Analisis hasil uji kompetensi dan hasil respon siswa mendapatkan kriteria yang sangat baik dari semua siswa dengan nilai rata-rata 81,18.

5. Tahap Evaluasi

Pada tahap ini sudah tidak dilakukan perbaikan terhadap media yang dikembangkan karena dilihat dari respon siswa menunjukkan hasil baik. Jadi dapat disimpulkan produk akhir yang dihasilkan peneliti dikategorikan baik atau layak digunakan sebagai media ajar dalam pembelajaran matematika di sekolah. 


\section{SIMPULAN DAN SARAN}

Berdasarkan hasil penelitian dan menjawab tujuan penelitian, maka penelitian ini dapat disimpulkan bahwa, peningkatan kemampuan komunikasi matematis melalui bahan ajar yang dikembangkan berbasis pembelajaran matematika realistik siswa SD Negeri 060791 Medan Area. Hal ini ditunjukkan dengan hasil $\mathrm{N}$-Gain yang diperoleh kelas eksperimen 1 sebesar 0,71 dengan kategori tinggi sedangkan kelas eksperimen 2 hanya berada pada nilai 0,49 dengan kategori sedang.Produk bahan ajar berbasis Pembelajaran Matematika Realistik efektif digunakan dalam meningkatan kemampuan komunikasi matematis siswa SD Negeri 060791

Medan Area. Produk bahan ajar efektif dengan karakter Self instructional (peserta didik mampu belajar dengan mandiri), Self Contained (tujuan pembelajaran jelas, belajar berdasarkan pengalaman atau kehidupan sehari-hari) dan User friendly (mampu berdiskusi serta mengkomunikasikan hasil dengan baik). Terdapat perbedaan kemampuan komunikasi matematis siswa antara siswa yang diberi pembelajaran matematis realistik dengan siswa pada pendekatan ekspositori siswa.

Berdasarkan hasil penelitian ini peneliti menyarankan Guru matematika lebih aktif lagi mengembangkan bahan ajar sesuai dengan tuntunan Kurikulum 2013, melalui implementasi pendekatan pembelajaran, latihan hingga cara yang tepat dalam mengevaluasi keberhasilan peserta didik. Kemudian mampu mengevaluasi Kompetensi Inti dalam setiap materi yang akan diselesaikan atau diberikan kepada peserta didik.

\section{DAFTAR RUJUKAN}

Afrom, I. (2019). Penerapan Pendekatan Saintifik Di Kelas V SDN-8 Palangka Kota Palangka Raya. Tunas: Jurnal Pendidikan Guru Sekolah Dasar, 5(1), 44-49.

Hasanah, A. (2012). Pengembangan profesi guru.

Islam, H. H. (2016). Penerapan Model Pembelajaran Pendıdıkan Matematıka Realıstık (Pmr) Untuk Meningkatkan Kemampuan Komunikası Matematıs Siswa SMP (Doctoral dissertation, FKIP UNPAS).

Kurbaita, G., Zulkardi, Z., \& Siroj, R. A. (2013). Pengembangan Buku Ajar Matematika Tematik Integratif Materi Pengukuran Berat Benda untuk Kelas I SD. KREANO, Jurnal Matematika Kreatif-Inovatif, 4(1), 1-10.

Purnama, I. M. (2016). Pengaruh kecerdasan emosional dan minat belajar terhadap prestasi belajar Matematika di SMAN Jakarta Selatan. Formatif: Jurnal Ilmiah Pendidikan MIPA, 6(3).

Sritresna, T. (2017). Meningkatkan Kemampuan Komunikasi Matematis dan Self-Confidence Siswa melalui Model Pembelajaran Cycle 7E. Mosharafa: Jurnal Pendidikan Matematika, 6(3), 419-430.

Sumiati, A., Widyastuti, U., \& Sariwulan, T. (2017). Workshop Pengembangan Bahan Ajar Modul Berdasarkan Pendekatan Scientific Pada Kurikulum 2013 Sebagai Sumber Pembelajaran Guru SMK Di Kabupaten Bekasi. Jurnal Pemberdayaan Masyarakat Madani (JPMM), 1(1), 86-95.

Umar, W. (2012). Membangun kemampuan komunikasi matematis dalam pembelajaran matematika. Infinity Journal, 1(1), 1-9. 